\title{
NEWSPAPER AND JOURNALISM FROM VIEWPOINT OF ARTHUR SCHOPENHAUER ${ }^{1}$
}

\author{
ARTHUR SCHOPENHAUER'IN GÖZÜNDEN GAZETE VE GAZETECİLIKK
}

\section{DOI:10.17755/esosder.90344}

\section{Eylem ŞENTÜRK KARA ${ }^{2}$}

\begin{abstract}
Nowadays, language errors made in the media have very often become an important issue on our agenda. There are a wide range of sources in the literature showing the language errors especially made by journalists both in Turkish and in other languages. In the 19th century, on one hand, as a result of developments in social and technological fields, the importance of newspaper and journalism increased gradually, and on the other hand, various criticisms started to come up related with this issue. Arthur Schopenhauer was at centre of heavy criticisms towards journalists during this period. As a result of misuse of the German language, Schopenhauer blamed journalists for deterioration of the language and heavily criticized them. The purpose of this study is to determine how Schopenhauer evaluated the concepts of newspaper and journalism and to analyse the meanings he had attributed to these concepts based on his books titled Über die, seit einigen Jahren, methodisch betriebene Verhunzung der deutschen Sprache and Der handschriftliche Nachlaß and Parerga und Paralipenoma.
\end{abstract}

Keywords: Arthur Schopenhauer, Journalism, Newspaper German, Newspaper writers

\section{$\ddot{\mathbf{O z}}$}

Günümüzde medyada yapılan dil yanlışları çok sık gündeme gelen bir konu olarak karşımıza çıkmaktadır. Özellikle gazeteciler tarafından yapılan dil yanlışlarının toplumların dillerine ne kadar fazla zarar verdiğini gösteren gerek Türkçe gerekse diğer dillerde literatürde çok sayıda kaynak bulunmaktadır. 19. yüzyılda siyasi, sosyal ve teknolojik alanlarda meydana gelen gelişmeler neticesinde bir yandan gazete ve gazeteciliğin önemi giderek artarken diğer yandan bu konuyla ilgili eleştiriler de gündeme gelmeye başlamıştır. Gazetecilere bu dönemde yöneltilen ağır eleştirilerin merkezinde Arthur Schopenhauer vardır. Schopenhauer, Alman dilinin yanlış kullanılması neticesinde dildeki bozulmanın temel suçlusu olarak gazetecileri görmüş ve onları çok ağır bir şekilde eleştirmiştir. Bu çalışmanın amacı Schopenhauer'ın Über die, seit einigen Jahren, methodisch betriebene Verhunzung der deutschen Sprache ve Der handschriftliche Nachlaß ve Parerga und Paralipenoma adlı kitaplarından yola çıkarak onun gazete ve gazetecilik kavramlarını nasıl değerlendirdiğinin tespit edilmesi ile bu kavramlara yüklediği anlamların irdelemesidir.

Anahtar Kelimeler: Arthur Schopenhauer, Gazetecilik, Gazete Almancası, Gazete yazarları

\footnotetext{
${ }^{1}$ This study is revised and expanded version of the Report presented in "The 2015 WEI International Academic Conference Proceedings" in Barcelona/Spain between the dates 18-20 January, 2015.

${ }^{2}$ Assistant Professor, Inonu University, Faculty of Communication, Journalism Department, eylem.kara@inonu.edu.tr
} 


\section{Introduction}

Today, how language mistakes cause great damages to the language of their own communities come to the fore and especially journalists have been criticized because they are not sensitive enough on this issue. It is the 19th century period when language mistakes made in newspapers started to come to the fore. Arthur Schopenhauer who lived during this period is one of those who most severely criticized the journalists on this subject.

Arthur Schopenhauer who is the student of the famous philosopher Immanuel Kant is one of the most important language masters who pioneered many philosophers such as Nietzsche in German philosophy. In Europe, radical political, social and economic changes were experienced because some wars holding an important place in the history of world and economic crisis were seen intensely within the period in which he lived. As a result of failure of the revolutionary movement of 1848, a period of depression and capitalism started to rise in Germany. The experience of such important historical events in the 19th century also affected the history of the press deeply. During this period, while reading habit of people and number of newspapers were increasing due to the developments in the field political, social and technological developments, the language used in the press/media began to change (Pürer/Raabe, 1994, s.19).

During the period whenSchopenhauer lived, people were following only published newspapers in order to be informed what was happening around and to get the information they need due to technological reasons. Therefore, people were more affected by the newspapers than the present time. This effect was positive and beneficial and had an extremely important place in terms of development of the society's political, social, economic and cultural areas.It is of a great importance that especially these newspapers are being transferred to future generations without any corruption by using a correct and efficient language.

In the 19th century, a variety of discussions on writing and journalism were made intensely. Schopenhauer emphasizes that people need to write after developing with their experiences by saying for authorship "The pen is to think what the stick is to walking; but you walk most easily when you have no stick, and you think with the greatest perfection when you have no pen in your hand. It is only when a man begins to be old that he likes to use a stick and is glad to take up his pen" (Schopenhauer, 2007, s.63). Therefore, anybody cannot be author like anybody must not be a journalist.

Schopenhauer describing journalists as "newspaper writers", criticizes them by expressing the language they used as "Newspaper German" = "Language Mutilation".Schopenhauer who criticized the journalists by insulting, charges them with damaging the language by writing poor-quality daily articles for a certain fee. In addition, Arthur Schopenhauer showed journalists as the ones who were primary responsible for changes and corruption in the language.

In this study, criticisms of Schopenhauer on the journalists and the language ("Zeitungsdeutsch" = "Sprachverhunzung") they used are analyzed based on his books named Über die, seit einigen Jahren, methodisch betriebene Verhunzung der deutschen Sprache and Der handschriftliche Nachlaß and Parerga und Paralipenoma. The underlying causes of these criticisms have been presented in the study.

\section{Life of Arthur Schopenhauer}

The German philosopher Arthur Schopenhauer who is the founder of the philosophy of Pessimism was born on February 22, 1788, in Danzig (Gdańsk) which is now within the land of Poland. His father is Heinrich Floris Schopenhauer and his family immigrated 
necessarily to Hamburg as King of Prussia attacked Danzig in 1793 (Hölterhof, 2012, s.10; Gwinner, 2013, s.20). Arthur Schopenhauer who continued his education here accompanied his father during business trips because his father wished to bring him up as "a good merchant and a gentleman". Through these travels, Heinrich Floris wanted her son both to learn trade and know the world (Hübscher, 1938, s.12).

As language training was also very important for him, he read the news in English and French newspapers (especially the Times) every day for him to improve his son's English and French (Hübscher, 1938, s.11). When he was nine years old, his father sent him to a family friend in Paris to learn social grace and Arthur returned to his family after living there for two years (Schirmacher, 1994, s. XIX). On the one hand, Schopenhauer increased his commercial knowledge and experience, on the other hand, he gained a universal depth of thinking by reading important philosophers thanks to the business trips he made and the education he received in England and France with the support of his father. During this period, he met the worksof writers and philosophers such as Voltaire and Rousseau who left their markson the $18^{\text {th }}$ century and he was influenced by them (Gwinner, 2013, s.21).Arthur, who showed a great interest in literature and philosophy, did not want to be a merchant.But, nevertheless, as a result of his father's attempts he was apprenticed to the famous merchant Senator Jenisch from Hamburg in 1804. Arthur, who lost his father in 1805, continued the merchant apprenticeship for a while. However, Schopenhauer who could not recover himself after his father's suicide began mourning by going into a deep depression (Schirmacher, 1994, s. XIX). His mother, Johanna liquidated the family businesses and moved to Weimar from Hamburg after several months of mourning. Mother Johanna living a free life after the death of her husband, making parties in her house and make a large circle of friends, led Schopenhauer to meet with important people (Hölterhof, 2012, s.13-14). Among the participants in this special invitation to her house in Weimar, there were also people such as Wieland, Heinrich Meyer, Johannes Falk, Karl Ludwig Fernow, Zacharias Werner, Goethe and Friedrich Major who were important German writers and poets of that period. Arthur met Goethe in one of these invitations (Gwinner, 2013, s.36-37).

Schopenhauer who began to read the Greek and Roman classics at a young age continued these readings during the university years. He stated that he cleared and developed his wording in German languageby this means. Arthur who began his medical training at the University of Göttingen in 1809 read books of famous philosophers like Kant and Plato on the one hand and laid the foundations of philosophy education (Schirmacher, 1994, s. XX; Koßler, 2015). Schopenhauer who went to the University of Berlin in 1811 tried to develop himself by attending the courses in different departments here. He took the Greek and Latin literature lessons from F. August Wolf, History of Philosophy from Schleiermacher, Electric and Magnetic from Paul Erman, Animals and Chemistry from Klaproth, Astronomy from Bode and Brain Anatomy from Rosenthal. He gained the title of Doctorate for his work named Die Vierfache Wurzel des Satzes vom Zureichenden Grunde (On the Four fold Root of the Principle of Sufficient Reason) in Jena University in 1813 (Hölterhof, 2012, s.15). Uber Das Essen und die Farben (On Vision and Colors) which is one of his first published works was written in 1816 after meeting Goethe and adopting his theory of colours (Schneider, 1997, s. 155-164; Wissen Digital, 2015). His first great work Die Welt als Wille und Vorstellung (The World as Will and Representation) was published in 1818. Two years later, Schopenhauer became associate professor at the University of Berlin (Hölterhof, 2012, 15). His work Über den Willen in der Natur (On The Will in Nature) was published in 1836 and the work Über die Freiheit des menschlichen Willens (On the Freedom of the Will) was published in 1837. Schopenhauer won the award of Royal Norwegian Academy of Sciences in 1839. His work titled Die beiden Grundprobleme der Ethik (The Two Fundamental 
Problems of Ethics) was presented to the readers in 1841. He gained a reputation when his work Parerga und Paralipenoma (Greek for "Appendices" and "Omissions") that he published in 1851 was sold much more than expected. Parerga und Paralipenoma is a twovolume work consisting of Schopenhauer's philosophical essays and aphorisms. Revealing a critical portrayal of philosophers and movements of thought which had an important place in the history of philosophy from pre-Socratic philosophers to him, Schopenhauer expressed here how he positioned himself in the history of philosophy (Tanyol, 1998, s.15). With Parerga und Paralipenoma, his thoughts began to be discussed in foreign magazines and German magazines and his system began to be taught in European universities. He gained a group of fans around him, in the United Kingdom, Russia, and the United States before his death. He died on September 21, 1860 in Frankfurt am Main.

\section{Schopenhauer and Language}

Schopenhauer who had a unique writing style took private philology lessons from a very young age. With the influence of his father he had traveled to many countries since childhood, and received education in many countries, especially in Britain and France. This situation enabled him to learn classical languages and many modern European languages (Italian, Spanish, etc.) at a good level and to have extensive knowledge (Ackermann 1978, s.21-25). In addition to this, as Schopenhauer had a command of many language he had the opportunity to assess and read the texts of great writers and philosophers such as Plato, Dante, Shakespeare, Spinoza and etc. in the original language. While emphasizing how important reading the worksin their original language is, he likened reading the teachings of philosophers from history of philosophy books or from the reviews to being presented to us by someone else after being chewed Schopenhauer (2007, s.49).

French as well as German has a very important place in Schopenhauer's intellectual background. Although Schopenhauer found French insufficient in the field of poetry, he appreciated this language's clear narrative style in prose. Schopenhauer read the works of many people such as Montaigne, Helvetius, Rochefoucault, Chamfort and etc. in French originals (Sans 2003, s.9). Schopenhauer who was quite sensitive regarding incorrect use of language highlighted the importance of clear and simple writing style. Therefore, Schopenhauer was careful to use clear, simple and lively language far from verbiage (Sans 2003, s.10). In this regard, he is among a small number of successful philosophers who are successful with strong and fluent writing style in prose (Janaway, 2007, s.20).

\section{Arthur Schopenhauer's criticism of newspaper language}

In parallel to the significant innovations that took place in the scientific field in end of the 18th century and the middle of the 19th century, a number of developments occurred in education sector, as well. Firstly, as a result of the establishment of the large printing houses, greater number of books were started to be published. While there was an increase in the number of literate people, reading was no longer a luxury because of the increasingly widespread habit of reading. As a result of decreasing costs in economic terms, there was qualitative and quantitative increases in media sector (Pürer/Raabe, 1994, s.19). In parallel with all these developments, Schopenhauer emphasizes that there is a major corruption in the language used in the newspapers. Believing that especially the value of German Language (language) was decreased and fell into the hands of people who did not deserve Schopenhauer describes this situation as follows:

"But anything is allowed against the German language! It is in the hands of writers just because of the dear bread, of literati and badly paid professors" (Schopenhauer, 1997, s.68). 
Schopenhauer expresses that presenting everything in newspaper articles during his period in a hurry imprecisely and in a short form trivialized and made insignificant everything. He expresses this situation as follows:

"Everything short, just short! They are in a great hurry, for their own lives are abbreviated ones: They, as well as already their parents, only got their lives as a feud from the cowpox, as which everybody saves the weaklings of the children's world who in former times died on the touchstone of the real pox and left space for the strong who were to live and to beget children. This dynasty with their short lives, which they only got as a feud and therefore are so much under so much pressure, are those long-bearded dwarves who come across one's legs everywhere" (Schopenhauer, 1997, s. 64).

\subsection{The importance of the German language according to Schopenhauer}

Schopenhauer believed that the German language was superior in Europe, considering it to be the most highly developed European language.

"The German language is on a much higher level than any of the other European languages. (...) It is painful to watch a language rich with beautiful, old, classical texts being mistreated by ignorants and donkeys" (Schopenhauer, 1997, s.32).

"The German language has been handed over to stupidity. (...) Should we surrender such a language to the arbitrariness and mood and stupid lack of judgement of most unknowing botchers, newspaper writers, booksellers' assistants, and book manufacturers of all kinds in need of money?" (Schopenhauer, 1997, s.45).

"The German language is now free for every scribbler in the service of a bookseller or a paper blotting newspaper writer: if this continues, the German language, the language in which our classics used to write, will be a dead language within one hundred years. We will lack for words and grammatically clumsy jargon will be spoken, the work of the abovementioned reformators" (Schopenhauer, 1997, s.37).

Schopenhauer derived his understanding of language from classical literature and utilized this knowledge throughout every aspect of written language. He demanded that both the newspaper writer and the writer only writing to make a living should write no other language than the one which had been used by the classical poets of his nation.

\subsection{Reasons for the mutilation of the German language, according to Arthur Schopenhauer}

Arthur Schopenhauer criticized authors and writers for submitting the German language to their conventions, thus deforming its grammar and sense. In his opinion, the German language was misused for the newspaper writers' own purposes because having to write abstractly and having to use short descriptions, left room for many grammatical mistakes.

Schopenhauer criticizes anonymous writers as well.

"Mr Nobody; and everyone else is free to declare that Mr Nobody is a villain" (Schopenhauer, 1986, s.603).

"Mr Anonymous certainly Mr Villain, and you can bet one hundred to one that he who does not want to say his name intends to betray the audience. (...) Say who you are, villain, or keep silent!" (Schopenhauer, 1986, s.604).

Schopenhauer regarded his era as an impotent era in general, he spoke of a "poor time of usefulness", a "literary degenerate period" of which nothing will survive - except perhaps the mutilation of language. 
Regarding this negative development of language, Schopenhauer argues for a post-censorship, but only for a grammatical one and not for a regulation of contents (Schopenhauer, 1997, s.17).

\subsection{Schopenhauer: "Newspaper German" = "Language Mutilation"}

In the chapters "On Writing and Style" and "On Reading and Books" in the second volume of Parerga and Paralipomena (1851) Schopenhauer complained that the prevalence of professional mass writing was the most influential reason for a - mainly according to language - presumed downfall of German literature. In connection with this, he criticized the journalists very harshly. Schopenhauer affirmed these accusations in his posthumous text $O n$ The Mutilation OfThe German language Which Has Been Carried Out Methodologically For Several Years, written between 1856 and 1860.

"Each and every villain is a Lord of the language, for example every chap who escaped from an office or a shop and began to work for a newspaper writer. (...) At least the infamous jargon in which German papers are written most of the time should be branded as 'Newspaper German', and the youth should be warned not to learn grammar and spelling from these publications but rather recognize in which way one should not write" (Schopenhauer 1997, s.27; Schopenhauer 1975, s.77).

Schopenhauer despised "professional writers" as "paid footmen" of which neither spiritual nor linguistic achievements could be expected: "Every writer is getting worse as soon as he writes to gain profit." His main enemies among those "scribents" were the journalists who he accused of "ignorance, inability to judge and being mean".

"With what justification do the newspaper writers and journalists of a literary rundown period arrogate to reforming the language? They do it according to their standards of ignorance, their inability to judge and being mean. But scholars and professors who accept their improvements issue themselves a diploma of ignorance and being mean" (Schopenhauer 1997, s.27).

He was of the opinion that harmful influences of "political newspapers", which in his eyes constituted the lowest branch of literature, not only affected the use of language of the "uneducated ranks", but that of the scholars as well. He writes that during his times, the quality of literature and writing decreased compared to that of the previous century.

"Mostly born in political newspapers, the mutilated or impudently abused words find an unobstructed and honoured path into magazines published by universities and academies. Nobody withstands, nobody feels responsible to protect the language, but everybody follows this foolishness as though in a competition. (...) The political newspapers are especially active in the fields of language dilapidation; this lowest class of all printing writers, who just write for the day, on the day, and from day to day. I have already recommended putting them under police surveillance” (Schopenhauer, 1975, s.77).

Schopenhauer's attacks against "botchers and newspaper writers" show clearly that he identified the journalists, who turned to the "common folk" that he despised, with this very audience: "Without any circumstances I call them scribblers, though I know there are at least 10,000 of them: this doesn't intimidate me for a single moment: The mob has always been numerous, but nevertheless must always be treated as mob" (Fischer 1983, s.527).

He considered the press to have the largest and most dangerous influence on the language of the masses. Due to his estimation that more than 90 per cent of all those who were able to read and write read nothing but newspapers he decided that these contemporaries geared to the example of the press according to spelling, grammar, and style. He was of the 
opinion that the masses "in their simplicity" tended to consider the highhandedness and "language mutilation" as a "shortness of expression, elegant ease and sharp-witted improvement of the language", such as especially young uneducated people regarded the newspaper as an authority.

"As soon as any ignorant has written 'on the occasion' or 'based on', both of these expressions stare at us triumphantly from all books and magazines: because they have got an authority of their own. [...] If one has read a solecism 3 times, it is classical German to them" (Schopenhauer, 1975, s.83).

"There is no opposition against stupidity, but if someone committed a real folly all the others admire it and are in a hurry to copy it (...) They follow like sheep and they follow the donkeys" (Schopenhauer, 1986, s.649).

"The blamed mutilation of language, of which no other nation has an analogue, in most cases seems to come from the political newspapers, the lowest level of literature. From there, it finds its way to journals and ultimately to books. As far as I can see it doesn't meet any resistance, instead everybody is eager to be a contributor of those in a schematic desire to imitate and in a judgeless admiration of the absurd. As soon as I have been shocked by a new grammatical or orthographical folly I witness other writers eagerly adopting and copying it: every donkey is an authority unto its own" (Schopenhauer, 1997, s.26).

With such complaints Schopenhauer marks the press as the main culprit for the mutilation of language which he claims to exist and which he saw spreading, especially in the fields of spelling, grammar, word construction and syntax.

"They doodle in a hurry like paid footmen what they have to say with expressions which have just come into their unwashed mouths, without style, even without grammar or logic: they use the simple past instead of present perfect and past perfect, the ablative instead of the genitive, instead of all particles they only use one, 'for', which therefore is used wrongly five times out of six: they all commit the same follies" (Schopenhauer, 1986, s.641).

Schopenhauer's hostility towards newspapers was not limited to concrete stylistic faults or faults with regards to content in the German press of his times, he condemned the rise of mass journalism on a whole (on the other hand he was a regular reader of the "the Times" and other foreign newspapers; he often praised the linguistic advantages of the foreign and especially the English and French press several times).

"Even every English, French, Italian or Spanish writer strives to write elegantly, at least correctly, only the German writers don't, he even seems to try to just scribble as carelessly, basely, and incomprehensibly as possible (...) Therefore alone - not to mention other reasons - I prefer reading in any other language besides German; I feel real relief having finished such a German book and being able to turn to the other both new and old languages ..." (Schopenhauer, 1997, s.31).

Schopenhauer's critique of language used in newspaper articles greatly influenced numerous famous philosophers. Friedrich Nietzsche ${ }^{3}(1844-1900)$, took the criticisms of his former idol Schopenhauer one step further when he was quoted as saying "pigs' German sorry! Newspaper German".

\footnotetext{
${ }^{3}$ Nietzsche said: "I am one of those readers of Schopenhauer's who, after having read the first of his pages, know for sure that they will read every page and listen to every single word he said at all. I trusted in him immediately and I still trust in him as I did many years ago. I understood him as if he had written just for me" (Nietzsche Spuren 2015).
} 
Schopenhauer scornfully commented on the job title "journalist": "Precisely named! That would mean day labourer." Nietzsche despised the time bondage of the press, called it day labouring and regarded newspaper writers as "paper slaves of the day".

Unlike Schopenhauer, Nietzsche conceded that the majority of journalists did possess at least a basic education. He considered their education to be stunted (Fischer, 1983, s.529532) due to a lack of idols and targets typical of that time period.

\section{Closing remarks}

Schopenhauer was a language artistand along with Nietzschecould probably be considered the best stylist among German speaking philosophers. He lived in a time of tremendous social changes. During this time, many events took places which were important for press and world. These events affected Schopenhauer's life and his criticism of newspaper language.

Schopenhauer regarded writers and journalists as the main culprits for the decline of the German language which took place according to him. He believed they spoiled spelling, grammar, and etymology.

He criticised newspapers and their language in his satirical, language-critical manifests ("On Writing and Style", "On Reading and Books" in the second volume of "Parerga and Paralipomena" and "On the Adulteration of the German Language") which has been carried out methodically for several years. Schopenhauer originally wanted to utilize his criticism of the use of language as an opportunity to criticise capitalistic and democratic opinions. He was from an elite family, and therefore greatly opposed the poorly educated writing. He claimed that "in Germany the rotten academic, in the Romanic countries the artistically educated people would become journalists."

Journalists are not only responsible for the transference of information; as language experts, they serve an educational purpose as well. As masters of their language, society has granted them the authority to pass on information. This simply means that the written and spoken word of the journalists is always considered truthful as well as factual. Journalists have an added responsibility due to their enormous influence on the opinion construction processes in their communities. As Schopenhauer said, "Every letter is like a precious diamond, therefore the journalist is obliged to respect and protect the rules of their language."

\section{References}

Ackerman, Bade (1978): Schopenhauer und die deutsche Sprache, Freiburg, Schweiz: Universitätsverlag Freiburg.

Fischer, Dieter (1983): Von Börnezu Kraus: Auseinandersetzungen um die Zeitung und ihre Publizistik, 23.Jg., Konstanz: Universitätsverlag, S.525-546.

Gwinner, Wilhelm (2013): Arthur Schopenhauer: Auspersönlichen Umgang dargestellt, Bremen: Europaeischer Literatur Verlag.

Hölterhof, Tobias (2012): Anthropologie des Leidens: Leidensphilosophie von Schopenhauer bis Scheler. Düsseldorf: Heinrich Heine Universität.

Hübscher, Arthur (1938): Arthur Schopenhauer: ein Lebensbild mit 2 Handschriftproben

Janaway, Christopher (2007): Schopenhauer DüşünceninUstaları, Çev. R. Çağrı Ataman, İstanbul: Altın Kitaplar Yayınevi. 
Leipzig: Brockhaus.

Koßler, Matthias (2015): Arthur Schopenhauers Leben und Werk, http://www.schopenhauer.de/index.php?option=com_content\&view=article\&id=61\&It emid=62, (Erişim tarihi: 20.11.2015).

Nietzsche Spuren (2015): Erwachen, http://www.friedrichnietzsche.de/?REM_sessid=\&action=21\&start=19, (Erişim tarihi: 20.11.2015).

Pürer, Heinz; Raabe, Johannes (1994): Medien in Deutschland. Bd. I. Uvk, Konstanz: Medien Verlagsgesellschaft.

Sans, Édouard (2006): Schopenhauer; Çev. Işık Ergüden, Ankara: Dost Kitabevi Yayınları.

Schirmacher, Wolfgang(1994): Arthur Schopenhauer Philosophical Writings. Continuum German Library: Volume: 27. New York: New York University and Deutsches Haus.

Schneider, Walther (1997): Schopenhauer: eine Biographie. Hanau: Dausien.

http://www.suhrkamp.de/autoren/arthur_schopenhauer_4404.pdf, (Erişim tarihi: 20.11.2015).

Schopenhauer, Arthur (1962): İrade Felsefesive Schopenhauer, Derleyen: Sadi Irmak, İstanbul: İkbal Kitabevi.

Schopenhauer, Arthur (1975): Der handschriftliche Nachlaß, in 5 Bände/Arthur Schopenhauer, Hübscher, Arthur (Ed.) Frankfurt/Main: Kramer.

Schopenhauer, Arthur (Ed.) (1986): ÜberSchriftstellerei und Stil, in: Sämtliche Werke, Bd. V (Parerga und Paralipomena II) Frankfurt/Main: Suhrkamp Taschenbuch.

Schopenhauer, Arthur (1997): Über die, seiteinigen Jahren, methodisch betriebene Verhunzung der deutschen Sprache, Lütkehaus, Ludger (Ed.), Freiburg: Kore.

Schopenhauer, Arthur (2007): Parerga ve Parolipomena, Çev. Levent Özşar, İstanbul: Biblos Kitabevi Yayınları.

Tanyol, Cahit (1998): Schopenhauer'de Ahlak Felsefesi, İstanbul: Gendas Yay.

Wissen Digital (2015): Arthur Schopenhauer, http://www.wissendigital.de/Arthur_Schopenhauer, (Erişim tarihi: 20.11.2015). 